\title{
Further Evidence of Cucurbit Host Specificity among Acidovorax citrulli Groups Based on a Detached Melon Fruit Pathogenicity Assay
}

\author{
Lichun Yan, Baishi Hu, ${ }^{\dagger}$ Gong Chen, Mei Zhao, and Ron R. Walcott ${ }^{\dagger}$
}

First and second authors: College of Plant Protection and Key Laboratory of Integrated Management of Crop Disease and Pests, Ministry of Education, Nanjing Agricultural University, Nanjing 210095, China; and third, fourth, and fifth authors: Department of Plant Pathology, University of Georgia, Athens 30602.

Accepted for publication 15 June 2017.

\begin{abstract}
Bacterial fruit blotch, caused by the gram-negative bacterium Acidovorax citrulli, is a serious economic threat to cucurbit crop production worldwide. A. citrulli strains can be divided into two genetically distinct groups, with group I strains infecting a range of cucurbit species and group II strains being predominantly associated with watermelon. Group I and II $A$. citrulli strains differ in their arsenal of type III secreted (T3S) effector proteins and we hypothesize that these effectors are critical for cucurbit host preference. However, the pathogenicity or virulence assays used for A. citrulli, including infiltration of seedling cotyledons and mature fruit rind tissues with cell suspensions and spray inoculation of seedlings, lack the sensitivity to consistently distinguish strains of the two groups. Here, we describe an immature, detached melon fruit assay based on 'Joaquin Gold' melon (Syngenta, Rogers Brand) that clearly indicates differences in host specificity between group I and II A. citrulli strains. Using this assay, four group I strains (M6, AAC213-52, AAC213-55, and

XJL12) induced typical water-soaked lesions in melon fruit rind tissue 7 to 10 days after pinprick inoculation. In contrast, four group II strains (AAC00-1, AAC213-44, AAC213-47, and AAC213-48) did not induce water-soaked lesions on detached melon fruit rinds during the same period. These data suggest that group I A. citrulli strains have a specific capacity to infect immature Joaquin Gold melon fruit, whereas group II strains do not. Interestingly, this differential pathogenicity phenotype was not observed on foliar seedling tissues of the same melon cultivar, suggesting that host preference of A. citrulli strains is specific to immature fruit tissues. Using the immature melon fruit inoculation assay, a T3S system mutant of the group I A. citrulli strain, M6 (M6 $\Delta h r c V)$, failed to induce water soaking. This indicates that T3S effectors are involved in A. citrulli cucurbit host preference, and that this assay is suitable for future studies of unique T3S effectors that distinguish group I and II strains.
\end{abstract}

Acidovorax citrulli (Schaad et al. 1978, 2008; Willems et al. 1992 ) is the causal agent of bacterial fruit blotch (BFB), an economically important disease of watermelon and other cucurbit crop species worldwide (Isakeit et al. 1997; Langston et al. 1999; Martin and Horlock 2002; Martin et al. 1999). The disease was first reported in 1965 on watermelon seedlings of several plant introductions at the Georgia Agricultural Experiment Station in Griffin, GA (Webb and Goth 1965). Subsequently, BFB emerged as a threat to watermelon after several devastating outbreaks in commercial fruit-production fields in the United States in the late 1980s (Latin and Rane 1990; Somodi et al. 1991). Since then, BFB has caused substantial economic losses in cucurbit production around the world (Assis et al. 1999; Burdman and Walcott 2012; Burdman et al. 2005; Demir 1996; Hamm et al. 1997; Jacobs et al. 1992; Martin and Horlock 2002). A. citrulli is a seed-borne and seed-transmitted pathogen and infested seed are the most important source of primary inoculum for BFB outbreaks (Hopkins and Thompson 2002b; Latin and Hopkins 1995; Rane and Latin 1992). In the absence of commercially available cultivars with BFB resistance, the most important strategy for BFB management is the production and use of pathogen-free seed.

A. citrulli strains can be divided into two groups based on carbon substrate utilization profiles, SpeI genomic DNA digestion and pulsed-field gel electrophoresis (PFGE), repetitive element

†Corresponding authors; B. Hu: E-mail: hbs@njau.edu.cn, and R. R. Walcott: E-mail: rwalcott@uga.edu

*The $\boldsymbol{e}$-Xtra logo stands for "electronic extra" and indicates that two supplementary figures are published online.

(c) 2017 The American Phytopathological Society polymerase chain reaction (PCR), fatty acid methyl ester analysis, and multilocus sequence typing (Burdman et al. 2005; Feng et al. 2009; Walcott et al. 2000, 2004). In general, group I strains are isolated from a range of cucurbit species whereas group II strains are isolated predominantly from watermelon (Walcott et al. 2000, 2004). Using cucurbit seedling and fruit inoculation assays, Walcott et al. (2004) reported that group II strains were highly virulent on watermelon but mildly virulent on other cucurbit hosts. In contrast, group I strains were moderately aggressive on a range of cucurbits, including watermelon, melon, cucumber, and squash (Walcott et al. 2004). Similar findings were reported by O'Brien and Martin (1999) and Burdman et al. (2005) in Australia and Israel, respectively. However, true host specificity was not observed with artificial seedling and fruit inoculation assays (Walcott et al. 2004).

Recently, Zivanovic and Walcott (2017) reported that BFB incidence was significantly lower for melon seedlings ('Joaquin Gold') exposed to an A. citrulli group II strain (AAC00-1) than a group I strain (M6) in spray-inoculation and natural-pathogenspread experiments. Although these results supported the hypothesis of differential host preference for A. citrulli groups, the authors did not observe significant differences in temporal bacterial population dynamics between M6 and AAC00-1 after seedling tissue infiltration with bacterial cell suspensions (Zivanovic and Walcott 2017). Overall, the authors concluded that seedling-infiltration assays were inadequate for distinguishing $A$. citrulli groups, and suggested that fruit inoculation might be more informative. Based on this conclusion, the main objective of this study was to assess the ability of an immature cucurbit fruit inoculation assay to consistently distinguish group I and II A. citrulli strains in terms of virulence and pathogenicity. The rationale for using immature fruit is that, under natural field conditions, cucurbit fruit are susceptible to infection until 2 weeks after anthesis (Frankle et al. 1993). During this time, bacteria can penetrate ovary pericarp 
tissues through open stomata that are plugged by waxy deposits at later developmental stages. Additionally, previous attempts to compare A. citrulli groups by injecting $A$. citrulli cell suspensions into detached mature fruit tissues generally resulted in indiscriminate tissue rot (R. R. Walcott, unpublished data). A virulence or pathogenicity assay that objectively distinguishes group I and II A. citrulli strains would accelerate the discovery of unique virulence factors and inform the development of effective BFB management strategies.

Like most gram-negative, foliar, plant-pathogenic bacteria, A. citrulli requires a functional type III secretion system (T3SS) and type III secreted (T3S) effector proteins for pathogenicity and virulence. Recently, Eckshtain-Levi et al. (2014) reported that group I and II A. citrulli strains can be distinguished based on the sequences of select $\mathrm{T} 3 \mathrm{~S}$ effector genes. Using sequence similarity with known T3S effector genes, 11 putative T3S effector genes were identified in the genome of AAC00-1 (National Center for Biotechnology Information accession number NC_008752). Comparative sequence analysis of these effector genes from 22 group I and II A. citrulli strains revealed that Aave_2708 (hereafter, genes are named according to the old annotation of the AAC00-1 genome), a homolog of XopJ (YopJ family) (Üstün et al. 2013), was present in all tested group II strains but absent in all tested group I strains. Additionally, in group I strains, genes Aave_2166 (XopJ homolog) (Üstün et al. 2013) and Aave_3062 (AvrRxol homolog) (Zhao et al. 2004) had nucleotide deletions leading to open reading frame shifts and likely nonfunctional proteins. The authors hypothesized that the differences in the arsenals of T3S effectors among the three A. citrulli groups influence their patterns of aggressiveness and preferential association with different cucurbit species.

A long-term goal of our research is to characterize the contributions of key T3S effectors to the virulence and host preference of $A$. citrulli groups. This will require a simple, sensitive, and robust virulence assay. However, as discussed above, visual scoring of BFB symptom severity and quantification of temporal population dynamics in seedling tissue are inadequate for this purpose. Hence, a second objective of this research was to determine whether a detached, immature cucurbit fruit assay would have the sensitivity to detect the effects of T3S effector proteins secreted by $A$. citrulli strains.

\section{MATERIALS AND METHODS}

Bacterial strains, media, and inoculum preparation. The representative group I and II A. citrulli strains used in this study are listed in Table 1. All A. citrulli strains were grown at $28^{\circ} \mathrm{C}$ on Lysogeny Broth (LB) or LB agar plates and, when required, the culture media were supplemented with the following antibiotics: ampicillin at $100 \mathrm{mg} / \mathrm{ml}$ and rifampicin at $100 \mathrm{mg} / \mathrm{ml}$. To prepare A. citrulli inoculum, $5 \mathrm{ml}$ of $\mathrm{LB}$ was inoculated with a colony from a 48-h-old nutrient agar culture and incubated overnight at $28^{\circ} \mathrm{C}$ on a rotary shaker (Innova; New Brunswick Scientific, Edison, NJ) at $220 \mathrm{rpm}$. Cells were harvested by centrifugation at 13,000 $\times \mathrm{g}$ for $1 \mathrm{~min}$ and resuspended in $3 \mathrm{ml}$ of sterilized deionized distilled (sdd) $\mathrm{H}_{2} \mathrm{O}$. The optical density of cell suspensions was adjusted spectrophotometrically to 0.3 at $600 \mathrm{~nm}$ (approximately $0.5 \times 10^{8}$ CFU/ml) (Spectronic 20; Bausch and Lomb, Rochester, NY).

Pathogenicity of group I and II $A$. citrulli strains on detached melon fruit. To determine the suitability of a detached immature fruit assay for distinguishing group I and II A. citrulli strains, Joaquin Gold melon (Cucumis melo; Rogers Brand; Syngenta, Greensboro, NC) were grown under greenhouse conditions including average daily temperatures ranging from 25 to $33^{\circ} \mathrm{C}$, relative humidity $(\mathrm{RH})$ of $86 \%$, and $12 \mathrm{~h}$ of natural sunlight daily. Joaquin Gold melon was selected based on preliminary observations that indicated that its fruit was differentially susceptible to group I and II A. citrulli strains. Plants were fertilized (Peters Professional 20-10-20 Peat Lite, Special; Scotts-Sierra Horticultural Products Co., Marysville, $\mathrm{OH}$ ) weekly, and treated with Orthene (Chevron Chemical Co., Richmond, CA), Enstar II (Zoecon, Palo Alto, CA), Merit (Bayer, Montvale, NJ), and Avid (Syngenta) as required to control whiteflies, and Daconil (Syngenta) to manage powdery mildew. In this experiment, four group I (M6, AAC213-52, AAC213-55, and XJL12) and four group II (AAC00-1, AAC213-44, AAC213-47, and AAC213-48) A. citrulli strains were tested. At anthesis, female flowers were pollinated by transferring pollen from male flowers onto their stigmas. To ensure fruit development, petals of female and male flowers were removed at anthesis, and pollen from two to three male flowers was transferred to the stigmas of each female flower. Melon fruit were harvested 6 days after pollination, surface sterilized with $70 \%$ ethanol for $30 \mathrm{~s}$, rinsed twice with $\mathrm{sddH}_{2} \mathrm{O}$, and air dried for $1 \mathrm{~h}$ at room temperature. Fruit were cut into halves and placed (rind-side up) into humidity chambers composed of clear plastic, hinged, clamshell containers (Solo Container Corporation, Mason, MI) containing one layer of blotter paper saturated with $\mathrm{sddH}_{2} \mathrm{O}$. To prevent rapid melon fruit tissue decay during the assay, fruit were suspended above the moist blotter paper on 1-cm-high sterilized plastic blocks. Three wounds (approximately $2 \mathrm{~mm}$ deep and $2 \mathrm{~cm}$ apart) were made on the rind of each fruit half with a sterilized needle. Using a pipettor, $2 \mu \mathrm{l}$ of bacterial cell suspension (approximately $0.5 \times 10^{8} \mathrm{CFU} / \mathrm{ml}$ ) of each $A$. citrulli strain was applied to the surface of the wounds. Fruit inoculated with $\mathrm{sddH}_{2} \mathrm{O}$ in a similar manner served as negative controls. After air drying at room temperature, melon fruit halves were incubated at $28^{\circ} \mathrm{C}$ and $100 \%$ RH. At 7 to 10 days postinoculation (DPI), the diameters (longest length of each lesion) of water-soaked lesions were measured. Each A. citrulli strain was inoculated onto four immature melon fruit halves and mean diameters of the resulting lesions were measured. This experiment was conducted three times. Analysis of variance (ANOVA) was conducted using SAS 9.2 (SAS Institute Inc., Cary, NC) followed by Duncan's Multiple Range test $(P=$ $0.05)$ to determine the effect of bacterial strain and group on mean lesion diameter size.

Differences in temporal population dynamics between group I and II $A$. citrulli strains in detached melon fruit tissues. To investigate the differences in colonization of melon fruit tissue by group I and II A. citrulli strains, temporal population

TABLE 1. Acidovorax citrulli strains used in this study

\begin{tabular}{|c|c|c|c|c|c|}
\hline Strain & Host & Origin & Reference or source & PFGE haplotype ${ }^{a}$ & Group \\
\hline AAC213-44 & Watermelon & Unknown & R. Walcott & A3 (C) & II \\
\hline AAC213-47 & Watermelon & Thailand & R. Walcott & A2 (B) & II \\
\hline AAC213-48 & Watermelon & Unknown & R. Walcott & A5 (E) & II \\
\hline AAC00-1 & Watermelon & Georgia, United States & R. Walcott & A1 (A) & II \\
\hline AAC213-52 & Unknown & Unknown & R. Walcott & B13 (Y) & I \\
\hline AAC213-55 & Unknown & Unknown & R. Walcott & B9 (R) & $\mathrm{I}$ \\
\hline AACXJL12 & Melon & China & NAU Laboratory & B5 (M) & I \\
\hline M6 & Melon & Israel & Burdman et al. (2005) & B21 & I \\
\hline $\mathrm{M} 6 \Delta h r c V$ & Melon & Israel & Bahar and Burdman 2010 & B21 & I \\
\hline
\end{tabular}

${ }^{a}$ Pulsed-field gel electrophoresis (old designation in parentheses). 
dynamics of M6 and AAC00-1 were measured in detached immature melon (Joaquin Gold) fruit tissue. Ten Joaquin Gold fruit were generated and inoculated separately with $A$. citrulli strains M6 and AAC00-1, as described above. Pieces (approximately $1 \mathrm{~cm}^{3}$ ) of melon fruit tissue were sampled from the inoculation site at $0,2,4,6$, and 8 DPI. Fruit tissue samples were crushed in 1.5-ml microcentrifuge tubes, $1 \mathrm{ml}$ of $\mathrm{sddH}_{2} \mathrm{O}$ was added to each tube, and the homogenate was mixed for 2 min using a Vortex Genie 2 (Fisher Scientific, Waltham, MA). The supernatant $(900 \mu \mathrm{l})$ was transferred to a clean microcentrifuge tube and centrifuged at $13,000 \times g$ for $2 \mathrm{~min}$. The supernatant was discarded and the pellet was subjected to genomic DNA extraction using a commercial DNA extraction kit (E.Z.N.A. Bacterial DNA Kit; Omega Bio-Tek, Norcross, GA). Total DNA from each sample was concentrated into $35 \mu \mathrm{l}$ of elution buffer and $2 \mu \mathrm{l}$ of each was used for a real-time PCR assay. Populations of AAC00-1 and M6 in melon fruit tissue samples were quantified by a TaqMan real-time PCR assay using proprietary A. citrulli-specific primers and probe (UGA3979/UGA3979R and UGA 3979 PROBE, respectively) at concentrations of $0.3 \mu \mathrm{M}$ (for each primer) and $0.2 \mu \mathrm{M}$ (for the probe) in $25-\mu$ reaction volumes. The real-time PCR assay was conducted using the IQ Supermix reagent (Bio-Rad, Berkley, CA) and the following thermal profile: $95^{\circ} \mathrm{C}$ for $180 \mathrm{~s}$ followed by 40 cycles of $95^{\circ} \mathrm{C}$ for $20 \mathrm{~s}, 55^{\circ} \mathrm{C}$ for $30 \mathrm{~s}$, and $72^{\circ} \mathrm{C}$ for $30 \mathrm{~s}$. Cycle threshold $(\mathrm{Ct})$ values less than 35 were considered positive for A. citrulli and were converted into $\mathrm{CFU}$ per cubic centimeter of fruit tissue based on a standard curve. The standard curve was generated as follows. An A. citrulli suspension (approximately $1 \times 10^{8} \mathrm{CFU} / \mathrm{ml}$ ) was 10 -fold serially diluted to approximately $1 \times 10^{4} \mathrm{CFU} / \mathrm{ml}$. Aliquots $(1 \mathrm{ml})$ of each dilution were used for DNA extraction followed by real-time PCR assay, as described above. The experiment was conducted three times. Linear regression analysis was conducted on bacterial concentration $\left(\log _{10} \mathrm{CFU} / \mathrm{ml}\right)$ and corresponding $\mathrm{Ct}$ values and the resulting linear equation was used to calculate CFU per cubic centimeter of fruit tissue (Supplementary Fig. S1). This experiment was conducted two times and A. citrulli CFU per cubic centimeter of fruit tissue was plotted against time. Data from two replicates of the experiment were pooled to determine mean bacterial populations after preliminary statistical analysis showed no significant effect $(P>0.05)$ of replication and experiment. Temporal population dynamics curves for AAC00-1 and M6 were used to generate area under the population growth curve (AUPGC) data as follows:

$$
\mathrm{AUPGC}=\sum_{i=1}^{n}\left[\frac{Y_{i+1}+Y_{i}}{2}\right]\left[X_{i+1}-X_{i}\right]
$$

where $Y_{i}$ is $\log _{10}$ bacterial population at the $i$ th observation, $X_{i}$ is the time in days at the $i$ th observation, and $n$ is the total number of observations. ANOVA was conducted to determine the significance of the effect of strain on AUPGC data and least significant difference tests were conducted to compare the effects of $A$. citrulli strain on bacterial colonization of immature Joaquin Gold melon fruit tissue.

Pathogenicity of group I and II A. citrulli strains on immature fruit of other cucurbitaceous species. To determine whether group I and II A. citrulli strains displayed differential virulence on fruit of other cucurbit species: 'Magellan' melon (C. melo), 'Long Green Improved' cucumber (C. sativus), and 'Early Prolific Straightneck' squash (Cucurbita pepo) were tested. Cucumber, melon, and squash plants were grown as described above and, at anthesis, female flowers were pollinated and allowed to develop for 5 to 7 days. Fruit were harvested and inoculated separately with cell suspensions (approximately $0.5 \times$ $10^{8} \mathrm{CFU} / \mathrm{ml}$ ) of $A$. citrulli strains AAC00-1 and M6, as described above. Immature detached fruit of each species inoculated with $\mathrm{sddH}_{2} \mathrm{O}$ served as negative controls. Inoculated fruit were incubated at $28^{\circ} \mathrm{C}$ and $100 \% \mathrm{RH}$ for 7 to 10 days and fruit halves were visually inspected for water-soaked lesions. AAC00-1 and M6 were inoculated onto separate spots on the same immature fruit half of each cucurbitaceous species, and four fruit halves were inoculated per experiment. This experiment was conducted three times and the percentage of fruit halves that developed water-soaked lesions was recorded.

The role of T3S effectors in immature melon fruit infection by $A$. citrulli. T3S effectors are critical for $A$. citrulli pathogenicity on cucurbit seedlings and foliage (Bahar and Burdman 2010; Johnson et al. 2011). However, it was unknown whether their effects could be detected in the immature melon fruit inoculation assay. Hence, the detached immature Joaquin Gold melon fruit assay was used to test the T3SS mutant M6 $4 h r c V$. M6 $\Delta h r c V$ is incapable of inducing a typical hypersensitive response in leaves of tobacco plants (Bahar and Burdman 2010). M6 (wild type) and M6 $h r c V$ were compared using the detached, immature Joaquin Gold melon fruit assay, as described above, and fruit halves were visually examined for water-soaked lesions 7 to 8 DPI. Each strain was inoculated onto four melon fruit and the experiment was repeated three times. The percentage of fruit halves that developed watersoaked lesions was recorded.

Pathogenicity of $\boldsymbol{A}$. citrulli strains on cucurbit seedlings. To determine whether there is a difference in pathogenicity between A. citrulli strains AAC00-1 and M6 on melon seedlings, seedling growout assays were conducted, as previously described (Walcott et al. 2006). Thirty melon seeds (Joaquin Gold) were vacuum infiltrated for $40 \mathrm{~min}$ in $50 \mathrm{ml}$ of bacterial cell suspensions containing each $\mathrm{A}$. citrulli strain at approximately $1 \times 10^{6} \mathrm{CFU} / \mathrm{ml}$. Seed treated in the same manner with $0.1 \mathrm{M}$ phosphate buffered saline (PBS) served as a negative control. Treated seed were air dried for $24 \mathrm{~h}$ at room temperature and then individually planted in transparent test tubes ( 16 by $150 \mathrm{~mm}$ ) (Pyrex; Fisher Scientific, Pittsburgh) on cotton balls saturated with $\mathrm{sddH}_{2} \mathrm{O}$. Seed were incubated at $28^{\circ} \mathrm{C}$ and $100 \% \mathrm{RH}$ for 14 days and $\mathrm{BFB}$ incidence was recorded daily. This experiment was conducted three times and mean BFB incidence data were plotted against time. BFB incidence curves for AAC00-1 and M6 were used to generate area under the disease progress curve (AUDPC) data. ANOVA was conducted to determine the significance of the effect of strain on AUDPC data and least significant difference tests were conducted to compare the effects of $A$. citrulli strain on BFB seed-to-seedling transmission on melon.

\section{RESULTS}

Pathogenicity of group I and II strains of A. citrulli strains on detached melon fruit. Joaquin Gold melon fruit inoculated with group I A. citrulli strains developed water-soaked lesions by 8 DPI (Fig. 1A). In contrast, the group II strains induced little or no water soaking in the rinds of immature melon fruit (Fig. 1A). The effect of experiment on lesion diameter was not significant $(P=0.97)$; hence, data from the three experiments were pooled for statistical analysis. Mean diameters of water-soaked lesions induced by group I strains AAC213-52, AAC213-55, XJL12, and M6 were $0.71( \pm 0.13), 0.94( \pm 0.31), 0.5( \pm 0.08)$, and $0.67( \pm 0.15)$ $\mathrm{cm}$, respectively, whereas the mean diameters of lesions induced by group II A. citrulli strains AAC231-44, AAC213-47, AAC213-48, and AAC00-1 were 0, $0.03( \pm 0.08), 0.01( \pm 0.04)$, and $0.01( \pm 0.04)$ $\mathrm{cm}$, respectively (Fig. 2). Among group I A. citrulli strains, the mean rind lesion diameter induced by strain AAC213-55 was the largest $(P<0.05)$, followed by AAC213-52 and M6. Strain XJL12 induced the smallest mean lesion diameter among the group I strains. In contrast, there were no significant differences $(P=0.72)$ between the lesion diameters induced by group II A. citrulli strains or between the lesions induced by group II strains and the negative control (Fig. 2). The mean lesion diameter induced by the four group I A. citrulli strains $(0.71 \pm 0.24 \mathrm{~cm})$ was significantly $(P<$ $0.01)$ greater than that induced by the four group II strains $(0.01 \pm$ $0.04 \mathrm{~cm})$. 
Temporal population dynamics of AAC00-1 and M6 in Joaquin Gold melon fruit tissues. AAC00-1 and M6 populations increased over time in Joaquin Gold melon rind tissue after pinprick inoculation, and reached populations of $2.29 \times 10^{4}$ and $3.31 \times 10^{4} \mathrm{CFU} / \mathrm{cm}^{3}$ of fruit tissue, respectively, at $4 \mathrm{DPI}$ (Fig. 3A). However, between 4 and 8 DPI, the rate of AAC00-1 population growth declined and reached a maximum size of $5.89 \times$ $10^{4} \mathrm{CFU} / \mathrm{cm}^{3}$ (Fig. 3A). In contrast, populations of M6 increased by two orders of magnitude between 4 and 8 DPI and reached a maximum population size of $3.63 \times 10^{6} \mathrm{CFU} / \mathrm{cm}^{3}$ of melon fruit tissue. By $8 \mathrm{DPI}$, the population size of M6 in melon rind tissue was 100-fold higher than AAC00-1 (Fig. 3A). The differences between group I and II A. citrulli population growth in Joaquin Gold melon rind tissue between the two experiments were not significant $(P=0.95)$; hence, the data were pooled for statistical analysis. Based on the AUPGC data, AAC00-1 population growth in immature Joaquin Gold melon fruit tissue was significantly $(P<0.05)$ less than that of M6 (Fig. 3B).

Pathogenicity of $A$. citrulli strains AAC00-1and M6 on immature fruit of other cucurbitaceous species. As expected, pinprick inoculation of immature, detached cucumber, squash, and Magellan melon fruit with ssdH2O did not result in water-soaked lesions by 8 DPI. Additionally, none of the detached, immature squash and cucumber fruit developed water-soaked lesions after pinprick inoculation with A. citrulli strains AAC00-1 and M6 (Fig. $1 \mathrm{C}$ and D). Intriguingly, M6 did not induce water-soaked lesions by 8 DPI on detached, immature fruit of Magellan melon (Fig. 1B). As observed with Joaquin Gold melon, AAC00-1 was unable to induce water-soaked lesions on detached immature fruit of Magellan melon.
The effects of $A$. citrulli T3S effectors can be detected in the detached immature melon fruit assay. We investigated the ability of the detached melon fruit assay to detect the effects of T3S effectors by comparing the wild-type strain M6 to the T3SS mutant M6 $4 h r c V$. At 7 to 10 days after pinprick inoculation with approximately $1 \times 10^{8} \mathrm{CFU} / \mathrm{ml}$, M6 induced water-soaked lesions in $75 \%$ (9 of 12) of fruit samples tested (Fig. 4). In contrast, M6 $4 h r c V$ did not induce water-soaked lesions in 12 of 12 melon fruit tested.

Comparison of BFB incidence in Joaquin Gold melon seedlings caused by $A$. citrulli strains AAC00-1 and M6 seed-to-seedling transmission assays. To determine whether the differences in host preference observed for group I and II A. citrulli strains on immature Joaquin Gold melon fruit occurred on seedlings, seed-to-seedling transmission assays were conducted. Three experiments were conducted and, because the effect of experiment on BFB incidence was not significant $(P=0.91)$, data were pooled for statistical analysis. As expected, none of the seed lots inoculated with $0.1 \mathrm{M}$ PBS yielded seedlings with BFB symptoms. Seed samples inoculated with $A$. citrulli strains M6 and AAC00-1 started showing water-soaked lesions on cotyledons by 4 days after planting (DAP). BFB incidence in melon seedlings from seed inoculated with M6 and AAC00-1 were 37.7 and 22.6\%, respectively, by 5 DAP and 75.7 and $80 \%$, respectively, by 14 DAP (Fig. 5). Based on the statistical analysis of the AUDPC data, there was no significant difference $(P=0.77)$ between AAC00-1 and M6 in BFB seed-to-seedling transmission on melon seedlings (data not shown).

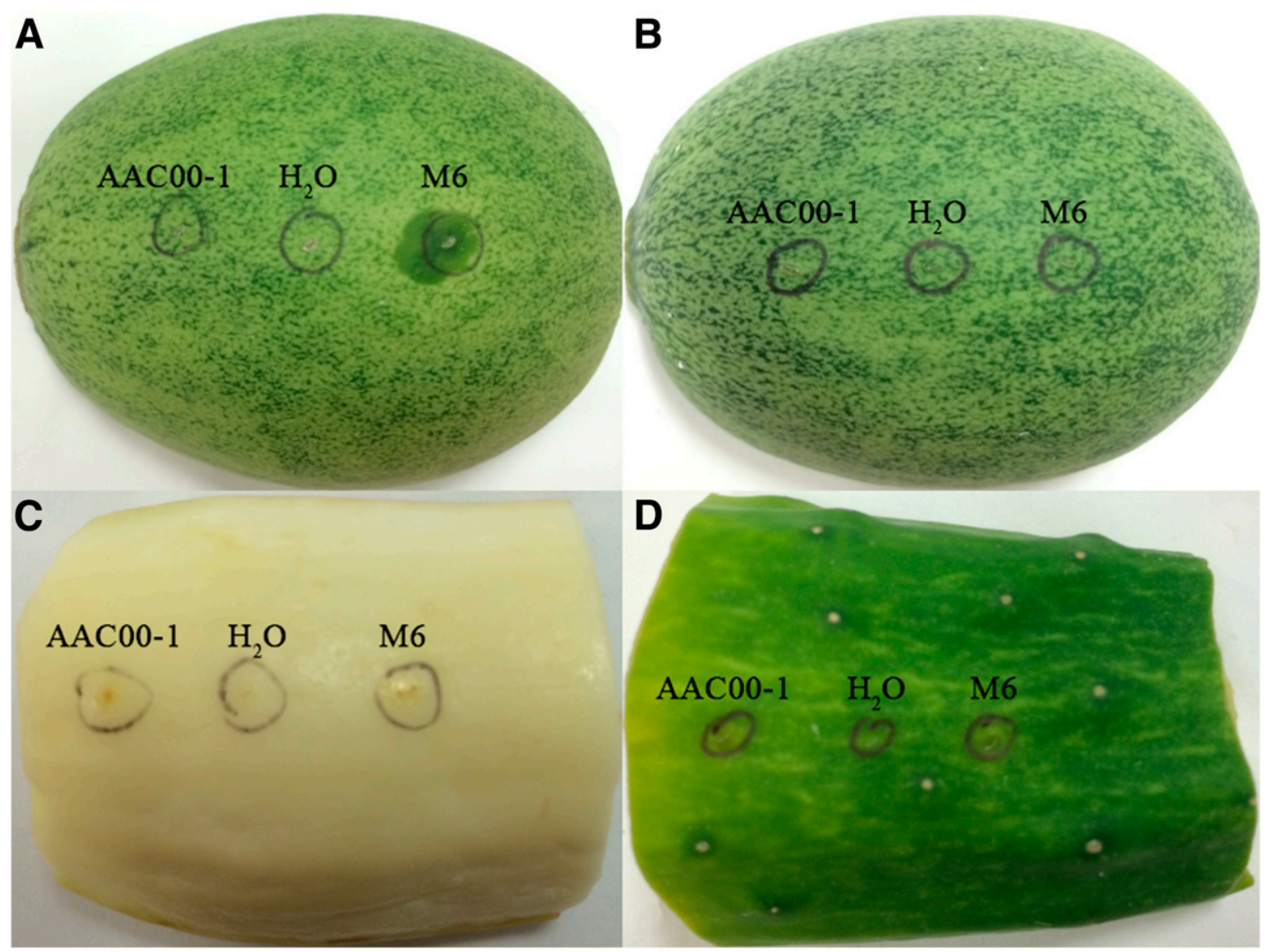

Fig. 1. Pathogenicity of Acidovorax citrulli strains AAC00-1 (group II) and M6 (group I) on detached A, Joaquin Gold melon (Cucumis melo); B, Magellan melon (C. melo); C, Early Prolific Straightneck squash (Cucurbita pepo); and D, Long Green Improved cucumber (Cucumis sativus) immature fruit. Melon fruit (5 to 7 days old) were produced under greenhouse conditions by hand pollination. Fruit were cut in half and inoculated with $2 \mu \mathrm{l}$ of cell suspensions containing $10^{8} \mathrm{CFU} / \mathrm{ml}$. Fruit halves were incubated at $28^{\circ} \mathrm{C}$ and $100 \%$ relative humidity for 8 days. The experiment was conducted three times and each treatment was replicated three times per experiment. 


\section{DISCUSSION}

A. citrulli strains are generally divided into two genetically distinct groups. However, it has been difficult to consistently demonstrate differences between strains in these groups in terms of virulence on various cucurbitaceous species (Burdman et al. 2005;

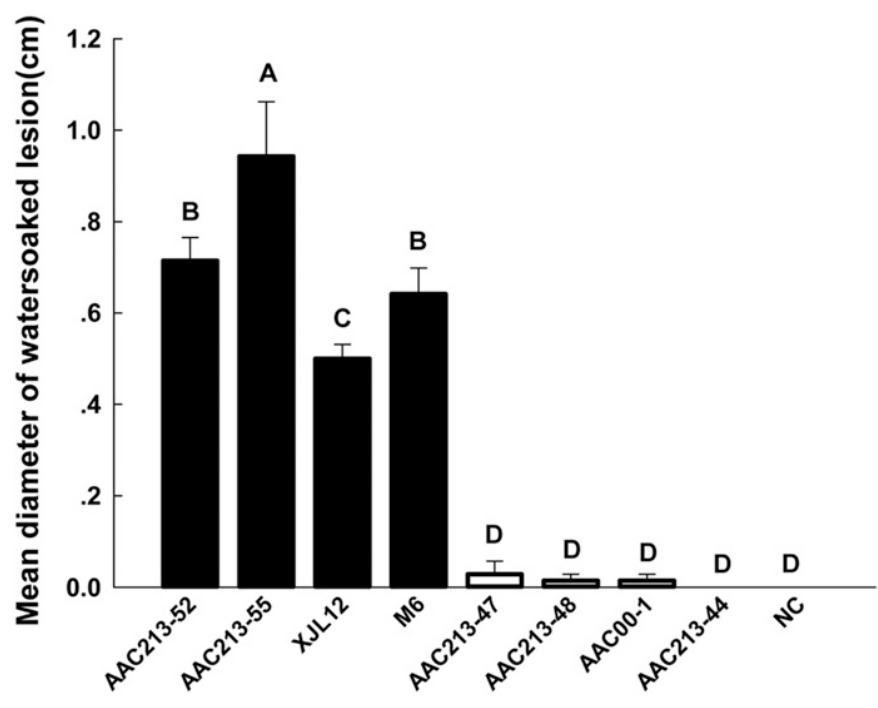

\section{Acidovorax citrulli strains}

Fig. 2. Mean lesion diameters induced by eight different Acidovorax citrulli strains representing groups I and II on detached Joaquin Gold melon (Cucumis melo) fruit after pinprick inoculation. Female melon flowers were pollinated and, after 5 to 7 days, fruit were harvested, cut in half, and pinprick inoculated with $2 \mu \mathrm{l}$ of cell suspensions (approximately $10^{8} \mathrm{CFU} / \mathrm{ml}$ ) of each strain. Fruit halves were incubated for 8 days at $28^{\circ} \mathrm{C}$ and $100 \%$ relative humidity and lesion diameters were measured. This experiment was conducted three times and each treatment was replicated three times per experiment. Bars represent the mean lesion diameter, lines represent the standard error of the mean, and different letters indicate significant difference based on Duncan's Multiple Range Test $(P=0.05)$.
Eckshtain-Levi et al. 2014; Feng et al. 2009; Walcott et al. 2000, 2004). Because A. citrulli groups differ in their arsenal of T3S effectors (Eckshtain-Levi et al. 2014), it is our long-term goal to elucidate the contributions of unique effectors to $A$. citrulli virulence and cucurbit host preference. The assays routinely used to assess $A$. citrulli virulence include seed-to-seedling transmission and spray and infiltration inoculation of seedlings and mature fruit (Burdman et al. 2005). In general, BFB severity is assessed visually based on a disease rating scale (Hopkins and Thompson 2002a). Unfortunately, these assays lack the sensitivity and robustness to effectively measure the contributions of T3S effectors to A. citrulli virulence. Additionally, Zivanovic and Walcott (2017) showed that monitoring A. citrulli colonization of melon and watermelon seedlings after tissue infiltration with bacterial cell suspensions did not reliably distinguish group I and II A. citrulli strains. Hence, a more sensitive and robust assay is needed to characterize differences in virulence between group I and II A. citrulli strains.

In this study, we showed that pinprick inoculation of detached, immature Joaquin Gold melon fruit definitively distinguished AAC00-1 from M6 in terms of pathogenicity. More specifically, the representative group I strain, M6, induced water-soaked lesions on detached, immature melon fruit by 8 DPI, whereas AAC00-1 did not. This differential pathogenicity phenotype was also observed for other group I and II A. citrulli strains that represent distinct SpeI PFGE haplotypes.

Our data indicate that $A$. citrulli host preference is strongly expressed in immature cucurbit fruit tissue. Burdman et al. (2005) independently explored the feasibility of a virulence assay based on melon and watermelon fruit based on injection of bacterial cell suspensions into mature fruit rind tissues (Burdman et al. 2005). However, such assays can produce experimental artifacts, because fruit infection naturally occurs up until 2 to 3 weeks after anthesis via open rind stomata, rather than at maturity (Frankle et al. 1993). Additionally, infiltration inoculation of mature fruit does not provide sufficient sensitivity to distinguish strains of $A$. citrulli groups (R. R. Walcott, unpublished data). In contrast, the immature detached melon fruit assay represents in a more realistic fruit infection process because the bacterial suspension is applied to the
A

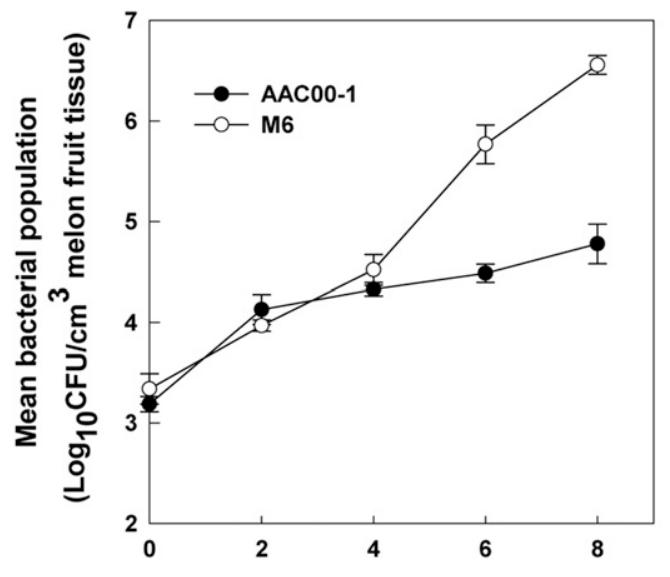

Time (days after inoculation)

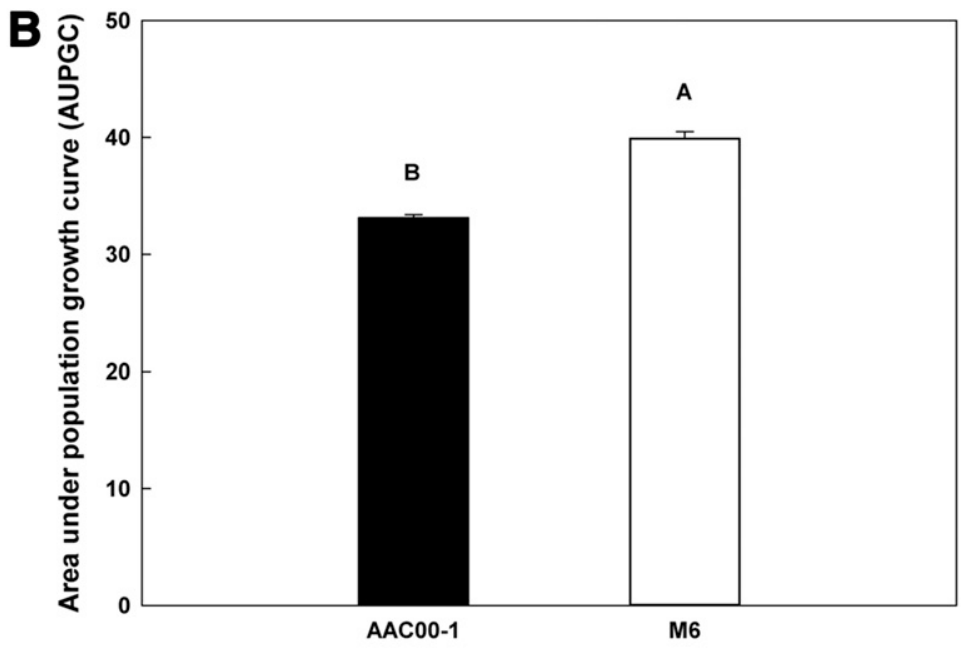

Acidovorax citrulli strains

Fig. 3. A, Comparison of temporal population growth of Acidovorax citrulli strains M6 (group I) and AAC00-1 (group II) in detached immature Joaquin Gold melon (Cucumis melo) fruit tissues. B, Bar chart of area under population growth curve (AUPGC) calculated of temporal population growth of AAC00-1 and M6. Under greenhouse conditions, female melon flowers were pollinated and, 5 to 7 days later, harvested, cut in half, and inoculated with $2 \mu 1$ of suspensions (approximately $1 \times 10^{8} \mathrm{CFU} / \mathrm{ml}$ ) of each strain. Inoculum was placed directly onto the fruit rind and fruit halves were incubated at $28^{\circ} \mathrm{C}$ and $100 \%$ relative humidity. At $0,2,4,6$, and 8 days postinoculation, approximately $1-\mathrm{cm}^{3}$ pieces (measuring the volume) of fruit tissues were harvested from the inoculation site, crushed, and subjected to microbial DNA extraction using an E.Z.N.A bacterial DNA kit (Omega Bio-Tek). DNA was subjected to quantitative real-time polymerase chain reaction (PCR) using an A. citrulli-specific TaqMan PCR assay. Using a dilution curve, cycle threshold values were converted to $\log _{10}$ CFU values. Data points represent mean $\log _{10} \mathrm{CFU}$ per cubic centimeter values. This experiment was conducted two times and each treatment was replicated four times per experiment. Lines represent standard errors of the means and different letters above the bars indicate a significant difference between AAC00-1 and M6 based on Duncan's Multiple Range Test $(P=0.05)$. 
surface of a pinprick wound in the rind, and the immature fruit is the stage at which fruit infection naturally occurs (Frankle et al. 1993). To the best of our knowledge, this is the first study to demonstrate cucurbit host specificity of $A$. citrulli groups in a detached melon fruit assay.

One interesting finding in this study was that, among the cucurbitaceous species tested (including watermelon, cucumber, melon, and squash), only Joaquin Gold melon yielded water-soaked symptoms in the detached immature fruit assay. The fact that symptoms did not develop on fruit of Magellan melon confirms that

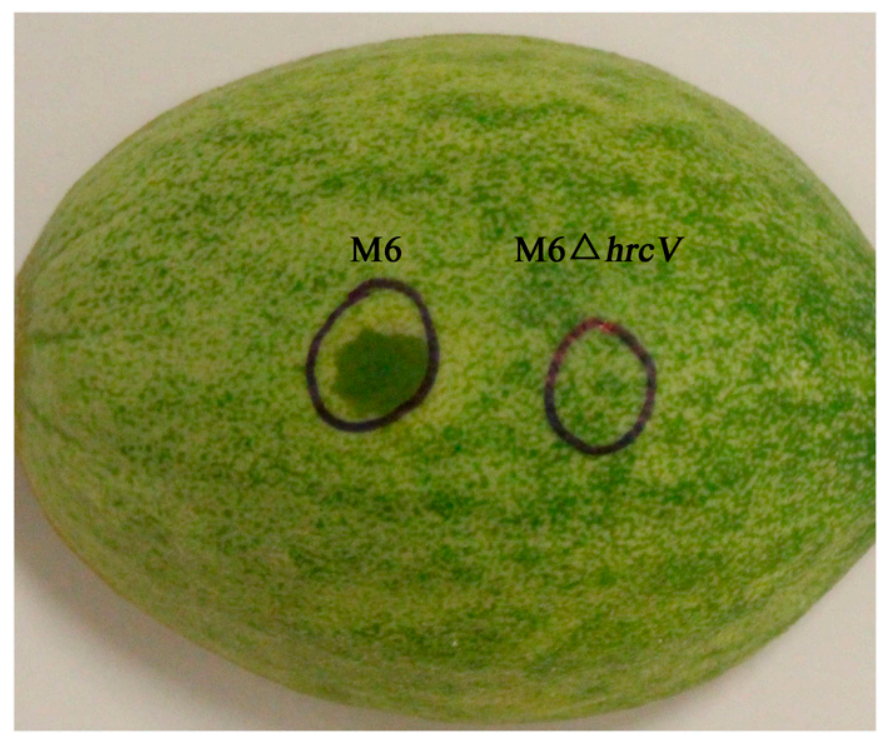

Fig. 4. Pathogenicity of Acidovorax citrulli strain M6 (group I) and type III secretion system mutant M6 $\Delta h r c V$ on detached immature Joaquin Gold melon (Cucumis melo) fruit. Under greenhouse conditions, female flowers were pollinated and, after 5 to 7 days, melon fruit were harvested, cut in half, and pinprick inoculated with $2 \mu \mathrm{l}$ of cell suspensions (approximately $1 \times 10^{8} \mathrm{CFU} / \mathrm{ml}$ ). Fruit halves were incubated at $28^{\circ} \mathrm{C}$ and $100 \%$ relative humidity and pictures were taken at 8 days postinoculation. This experiment was conducted three times and each treatment was replicated three times per experiment.

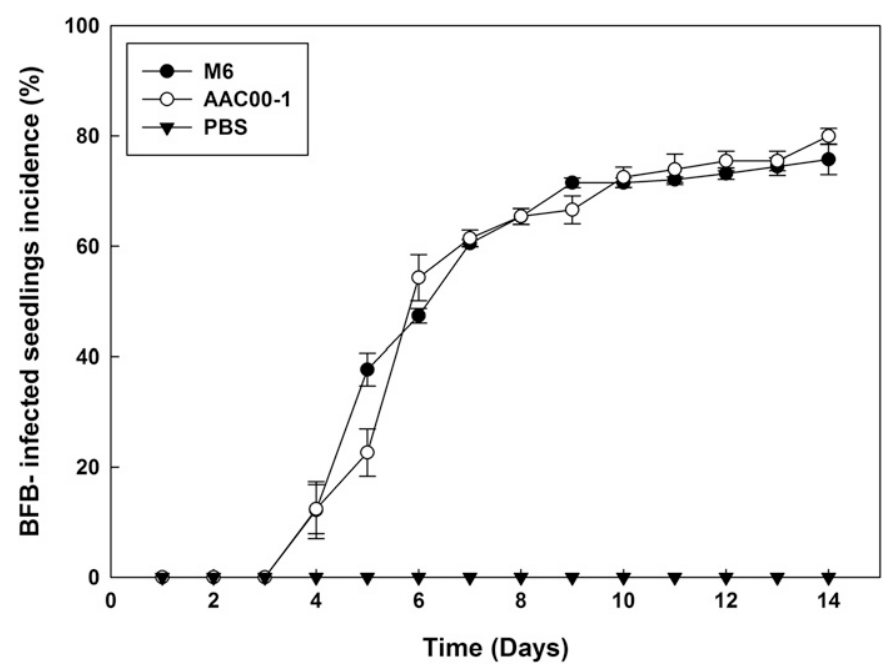

Fig. 5. Pathogenicity of Acidovorax citrulli strains M6 (group I) and AAC00-1 (group II) on melon (Joaquin Gold) seedlings based on the seedling grow-out assay. Bacterial fruit blotch (BFB) seedling transmission was determined based on the mean percentage of seedlings displaying water-soaked lesions along the midveins of cotyledons. Seedling transmission $=$ (number of seedlings displaying BFB symptoms/number of seedlings germinated) $\times 100 \%$. Data points indicate the mean BFB seedling transmission percentage and lines represent the standard error of the mean. This experiment was conducted three times. certain melon types display variable responses to A. citrulli infection, as previously reported (Bahar et al. 2009; Wechter et al. 2011). However, previous BFB resistance screens on melon were conducted using seed-to-seedling transmission and seedling inoculation techniques rather than fruit inoculation assays. More importantly, only immature fruit of Joaquin Gold melon distinguished group I and II $A$. citrulli strains. In a subsequent screen of other melon cultivars, we observed that immature fruit of 'Athena' melon also distinguished group I and group II A. citrulli (Supplementary Fig. S2). This proves that the differential pathogenicity phenotype observed for group I and II A. citrulli strains is not unique to fruit of Joaquin Gold. Additionally, unlike Joaquin Gold, Athena is a commercial cultivar that is widely available. At present, we have no explanation for the different responses observed for the three melon cultivars tested. However, we suspect that these differences might be due to fruit rind characteristics. For example, Magellan melon is a western type whose fruit develop ropey, even netting and no sutures (grooves) at maturity (Wehner 2002). In contrast, Athena melon is an eastern type hybrid with a tough, coarse netting and minor netted sutures at maturity. Unfortunately, there is limited information in the literature regarding the fruit rind characteristics of Joaquin Gold (Wehner et al. 2013). It will be important to screen additional melon cultivars for the differential pathogenicity phenotype and to investigate the rind characteristics that might influence bacterial invasion and infection.

Although the detached immature melon fruit assay can be useful for elucidating factors that influence $A$. citrulli virulence and host preference, it has some disadvantages. For example, obtaining young melon fruit may be difficult because of low rates of success with hand pollination rate (e.g., $30 \%$ for Joaquin Gold). Additionally, immature melon fruit tissues decay rapidly under high moisture conditions, which limits the period during which the pathogenicity assay can be conducted. Although further optimization is necessary, this assay is a substantial improvement over seedling inoculation assays in terms of ease of implementation and interpretation.

This study is the first to demonstrate the role of A. citrulli T3S effectors in melon fruit infection and host preference. Other studies of phytopathogenic bacteria have shown that $\mathrm{T} 3 \mathrm{~S}$ effectors are critical for host range determination. For example, Jones et al. (1998) reported that some Xanthomonas vesicatoria strains were virulent on both pepper and tomato plants, whereas most strains cause disease on only one of the two species. They also reported that the T3S effector protein AvrBsT was present in strain Bv5-4a, which was virulent only on tomato. Ciesiolka et al. (1999) also demonstrated that avirulence in the tomato group of $X$. euvesicatoria was controlled by the AvrBsT gene. Interestingly, Kim et al. (2010) introduced AvrBsT into a virulent pepper strain of $X$. euvesicatoria, Ds1, which rendered it avirulent to pepper plants. Finally, Angot et al. (2006) reported that Ralstonia solanacearum lost the ability to cause disease on Medicago truncatula after disruption of the GALA7 gene that encode a T3S effector. We hypothesize that unique effectors in group I and II A. citrulli strains contribute to host preference in immature Joaquin Gold melon fruit and we aim to investigate the roles of these effectors in cucurbit host specificity. The detached immature melon fruit assay described here will be an asset for this line of research.

\section{ACKNOWLEDGMENTS}

This work was supported by research grant US-4734-14C from the United States-Israel Binational Agriculture Research and Development Fund and the State Scholarship Fund from China Scholarship Council (number 201406850020). We thank S. Burdman for kindly providing the A. citrulli M $6 \Delta h r c V$ strain.

\section{LITERATURE CITED}

Angot, A., Peeters, N., Lechner, E., Vailleau, F., Baud, C., Gentzbittel, L., Sartorel, E., Genschik, P., Boucher, C., and Genin, S. 2006. Ralstonia 
solanacearum requires F-box-like domain-containing type III effectors to promote disease on several host plants. Proc. Natl. Acad. Sci. USA 103: $14620-14625$.

Assis, S. M. P., Mariano, R. L. R., Silva-Hanlin, D. M. W., and Duarte, V. 1999. Bacterial fruit blotch caused by Acidovorax avenae subsp. citrulli in melon in the state of Rio Grande do Norte, Brazil. Fitopatol. Bras. 24:191.

Bahar, O., and Burdman, S. 2010. Bacterial fruit blotch: A threat to the cucurbit industry. Isr. J. Plant Sci. 58:19-31.

Bahar, O., Kritzman, G., and Burdman, S. 2009. Bacterial fruit blotch of melon: Screens for disease tolerance and role of seed transmission in pathogenicity. Eur. J. Plant Pathol. 123:71-83.

Burdman, S., Kots, N., Kritzman, G., and Kopelowitz, J. 2005. Molecular, physiological, and host-range characterization of Acidovorax avenae subsp. citrulli isolates from watermelon and melon in Israel. Plant Dis. 89: 1339-1347.

Burdman, S., and Walcott, R. 2012. Acidovorax citrulli: Generating basic and applied knowledge to tackle a global threat to the cucurbit industry. Mol. Plant Pathol. 13:805-815.

Ciesiolka, L. D., Hwin, T., Gearlds, J. D., Minsavage, G. V., Saenz, R., Bravo, M., Handley, V., Conover, S. M., Zhang, H., Caporgno, J., Phengrasamy, N. B., Toms, A. O., Stall, R. E., and Whalen, M. C. 1999. Regulation of expression of avirulence gene $a v r R x v$ and identification of a family of host interaction factors by sequence analysis of avrBsT. Mol. Plant-Microbe Interact. 12:35-44.

Demir, G. 1996. A new bacterial disease of watermelon in Turkey: Bacterial fruit blotch of watermelon (Acidovorax avenae subsp. citrulli (Schaad et al.) Willems et al.). J. Turk. Phytopathol. 25:43-49.

Eckshtain-Levi, N., Munitz, T., Zivanovic, M., Traore, S. M., Sproer, C., Zhao, B. Y., Welbaum, G., Walcott, R., Sikorski, J., and Burdman, S. 2014. Comparative analysis of type III secreted effector genes reflects divergence of Acidovorax citrulli strains into three distinct lineages. Phytopathology 104:1152-1162.

Feng, J. J., Schuenzel, E. L., Li, J. Q., and Schaad, N. W. 2009. Multilocus sequence typing reveals two evolutionary Lineages of Acidovorax avenae subsp. citrulli. Phytopathology 99:913-920.

Frankle, W. G., Hopkins, D. L., and Stall, R. E. 1993. Ingress of the watermelon fruit blotch bacterium into fruit. Plant Dis. 77:1090-1092.

Hamm, P. B., Spink, D. S., Clough, G. H., and Mohan, K. S. 1997. First report of bacterial fruit blotch of watermelon in Oregon. Plant Dis. 81:113.

Hopkins, D. L., and Thompson, C. M. 2002a. Evaluation of Citrullus sp. germ plasm for resistance to Acidovorax avenae subsp. citrulli. Plant Dis. 86: 61-64.

Hopkins, D. L., and Thompson, C. M. 2002b. Seed transmission of Acidovorax avenae subsp. citrulli in cucurbits. HortScience 37:924-926.

Isakeit, T., Black, M. C., Barnes, L. W., and Jones, J. B. 1997. First report of infection of honeydew with Acidovorax avenae subsp. citrulli. Plant Dis. 81:694.

Jacobs, J. L., Damicone, J. P., and McCraw, B. D. 1992. First report of bacterial fruit blotch of watermelon in Oklahoma. Plant Dis. 76:1185.

Johnson, K. L., Minsavage, G. V., Le, T., Jones, J. B., and Walcott, R. R. 2011. Efficacy of a nonpathogenic Acidovorax citrulli strain as a biocontrol seed treatment for bacterial fruit blotch of cucurbits. Plant Dis. 95:697-704.

Jones, J. B., Stall, R. E., and Bouzar, H. 1998. Diversity among xanthomonads pathogenic on pepper and tomato. Annu. Rev. Phytopathol. 36:41-58.

Kim, N. H., Choi, H. W., and Hwang, B. K. 2010. Xanthomonas campestris pv. vesicatoria effector AvrBsT induces cell death in pepper, but suppresses defense Responses in tomato. Mol. Plant-Microbe Interact. 23:1069-1082.

Langston, D. B., Walcott, R. R., Gitaitis, R. D., and Sanders, F. H. 1999. First report of a fruit rot of pumpkin caused by Acidovorax avenae subsp. citrulli in Georgia. Plant Dis. 83:199.
Latin, R. X., and Hopkins, D. L. 1995. Bacterial fruit blotch of watermelon. The hypothetical exam question becomes reality. Plant Dis. 79:761-765.

Latin, R. X., and Rane, K. K. 1990. Bacterial fruit blotch of watermelon in Indiana. Plant Dis. 74:331.

Martin, H. L., and Horlock, C. M. 2002. First report of Acidovorax avenae subsp. citrulli as a pathogen of Gramma in Australia. Plant Dis. 86:1406.

Martin, H. L., O’Brien, R. G., and Abbott, D. V. 1999. First report of Acidovorax avenae subsp. citrulli as a pathogen of cucumber. Plant Dis. 83:965.

O'Brien, R. G., and Martin, H. L. 1999. Bacterial blotch of melons caused by strains of Acidovorax avenae subsp. citrulli. Aust. J. Exp. Agric. 39: $479-485$

Rane, K. K., and Latin, R. X. 1992. Bacterial fruit blotch of watermelon-Association of the pathogen with seed. Plant Dis. 76:509-512.

Schaad, N. W., Postnikova, E., Sechler, A., Claflin, L. E., Vidaver, A. K., Jones, J. B., Agarkova, I., Ignatov, A., Dickstein, E., and Ramundo, B. A. 2008. Reclassification of subspecies of Acidovorax avenae as A. avenae (Manns 1905) emend., A. cattleyae (Pavarino, 1911) comb. nov., A. citrulli Schaad et al. 1978. comb. nov., and proposal of A. oryzae sp. nov. Syst. Appl. Microbiol. 31:434-446.

Schaad, N. W., Sowell, G., Jr., Goth, R., Colwell, R., and Webb, R. 1978. Pseudomonas pseudoalcaligenes subsp. citrulli subsp. nov. Int. J. Syst. Bacteriol. 28:117-125.

Somodi, G. C., Jones, J. B., Hopkins, D. L., Stall, R. E., Kucharek, T. A., Hodge, N. C., and Watterson, J. C. 1991. Occurrence of a bacterial watermelon fruit blotch in Florida. Plant Dis. 75:1053-1056.

Ustün, S., Bartetzko, V., and Bornke, F. 2013. The Xanthomonas campestris type III effector XopJ targets the host cell proteasome to suppress salicylicacid mediated plant defence. PLoS Pathog. 9:e1003427.

Walcott, R. R., Castro, A. C., Fessehaie, A., and Ling, K. 2006. Progress towards a commercial PCR-based seed assay for Acidovorax avenae subsp. citrulli. Seed Sci. Technol. 34:101-116.

Walcott, R. R., Fessehaie, A., and Castro, A. C. 2004. Differences in pathogenicity between two genetically distinct groups of Acidovorax avenae subsp. citrulli on cucurbit hosts. J. Phytopathol. 152:277-285.

Walcott, R. R., Langston, D. B., Jr., Sanders, F. H., Jr., and Gitaitis, R. D. 2000. Investigating intraspecific variation of Acidovorax avenae subsp. citrulli using DNA fingerprinting and whole cell fatty acid analysis. Phytopathology 90:191-196.

Webb, R. E., and Goth, R. W. 1965. A seedborne bacterium isolated from watermelon. Plant Dis. Rep. 49:818-821.

Wechter, W. P., Levi, A., Ling, K. S., Kousik, C. S., and Block, C. C. 2011. Identification of resistance to Acidovorax avenae subsp. citrulli among melon (Cucumis spp.) plant introductions. HortScience 46:207-212.

Wehner, T. C. 2002. Vegetable cultivar descriptions for North America list 26 2002. HortScience 37:15-78.

Wehner, T. C., Mou, B., Wehner, T. C., Wehner, T. C., Mou, B., McCreight, J. D., Havey, M. J., Mou, B., Scott, J. W., Ellington, T. L., and Wehner, T. C. 2013. Vegetable cultivar descriptions for North America list 272013. HortScience 48:245-286.

Willems, A., Goor, M., Thielemans, S., Gillis, M., Kersters, K., and Deley, J. 1992. Transfer of several phytopathogenic Pseudomonas species to Acidovorax as Acidovorax avenae subsp. avenae subsp. nov., comb. nov., Acidovorax avenae subsp. citrulli, Acidovorax avenae subsp. cattleyae, and Acidovorax konjaci. Int. J. Syst. Bacteriol. 42:107-119.

Zhao, B. Y., Ardales, E. Y., Raymundo, A., Bai, J. F., Trick, H. N., Leach, J. E., and Hulbert, S. H. 2004. The avrRxol gene from the rice pathogen Xanthomonas oryzae pv. oryzicola confers a nonhost defense reaction on maize with resistance gene Rxol. Mol. Plant-Microbe Interact. 17:771-779.

Zivanovic, M., and Walcott, R. R. 2017. Further characterization of genetically distinct groups of Acidovorax citrulli strains. Phytopathology 107:29-35. 